\title{
LONG-TERM USE OF POTASSIUM FERTILIZER FOR VEGETABLE CROPS IN THE UPCOUNTRY INTERMEDIATE ZONE
}

\author{
J:D.H. WIJEWARDENA and S.L. AMARASIRI* \\ Regional Agricultural Research and Development Centre, Bandarawela.
}

(Received: 16 September 1996; accepted: 09 January 1997)

\begin{abstract}
A long-term field experiment was conducted at Bandarawela on a Red Yellow Pódzolic soil during the ten cropping seasons commencing Maha 86/87. Four levels of potassium at rates of $0,25,50$ and $100 \mathrm{~kg} \mathrm{~K} \mathrm{~K}_{2} \mathrm{O}$ /ha were applied for each crop. Potato, cabbage, tomato, pole bean, cabbage, potato, cabbage, tomato, pole bean and cabbage were cultivated in this sequence. First three crops potato in Maha 86/87, cabbage in Yala 1987 and tomato in Maha 87/88 did not show any response, even at $100 \mathrm{~kg} \mathrm{~K} \mathrm{~K}_{2} \mathrm{O} /$ ha application. This may be due to the high initial $\mathrm{K}$ content of the soil. Thereafter there was response up to $25 \mathrm{~kg} \mathrm{~K}_{2} \mathrm{O} / \mathrm{ha}$ application for the pole bean in Yala 1988 and cabbage in Yala 1989 crops. Potato in Maha $89 / 90$ gave significantly highest yield at the level of $50 \mathrm{~kg} \mathrm{~K}_{2} \mathrm{O} / \mathrm{ha}$. However, cabbage in Yala 1990, tomato in Maha 90/91, pole bean in Yala 1991 and cabbage in Maha 91/92 crops showed response to $25 \mathrm{~kg} \mathrm{~K}_{2} \mathrm{O} / \mathrm{ha}$ and even up to $100 \mathrm{~kg} \mathrm{~K} \mathrm{O} / \mathrm{ha}$. Crops such as potato and pole beans can be categorized as "low K-removal" and cabbage as "high K-removal".After cultivation of low K removal crops such as potato and pole bean, the soil showed an increase of exchangeable $\mathrm{K}$ when $100 \mathrm{~kg} \mathrm{~K}_{2} \mathrm{O} / \mathrm{ha}$ was applied. Increase of soil $\mathrm{K}$ was seen when potassium is continuously applied to the same soil at the rate of $100 \mathrm{~kg} \mathrm{~K}_{2} \mathrm{O} /$ ha but the make up of the cropping sequence is an important factor to be considered. It appears that high yields of vegetables such as potato, tomato; cabbage and pole bean, could be obtained with $100 \mathrm{~kg} \mathrm{~K}_{2} \mathrm{O} / \mathrm{ha}$ per season application without any buildup of $\mathrm{K}$ in the soil. These results suggest that the application of $100 \mathrm{~kg} \mathrm{~K} \mathrm{~K}_{2} \mathrm{O} / \mathrm{ha}$ to vegetable crops such as potato, tomato, cabbage and pole bean per season is is necessary and it avoids the build up of high soil $\mathrm{K}$ in this soil with the high yields.
\end{abstract}

Key words: Cropping sequence; Potassium, Upcountry vegetables.

\section{INTRODUCTION}

The Upcountry Intermediate Zone of Sri Lanka lies between 600 and $1400 \mathrm{~m}$ above mean sea level. The topography comprises steeply dissected hills with rolling terrain. The mean minimum and maximum temperatures are about 15 and $27^{\circ} \mathrm{C}$ respectively. Average annual rainfall ranges between 1100 to 1400 $\mathrm{mm}$. The soils are mainly Red Yellow Podzolic ${ }^{1}$ with a $\mathrm{pH}$ range of $4.0-5.5^{2}$

The hill slopes are planted with potato and vegetables in rotation throughout the year. In the lowlands, rice is planted during January-March and harvested during May-July. Potato and vegetables follow rice in these lands upto the end of December. Almost all farmers in this region use inorganic fertilizer mixtures

\footnotetext{
"Present address: Department of Agriculture, Peradeniya.
} 
in combination with organic fertilizers such as cattle and poultry manure. The agriculture in the upcountry areas of Sri Lanka is considered as intensive cultivation of potato and vegetable crops. Use of high analysis fertilizers at high levels in this region has contributed towards the accumulation of plant nutrients in the soil. ${ }^{2}$

Potassium is one of the essential elements in the plant food, and one of the three that is generally in short supply in the soil, and limiting crop yields. Hence it often needs to be added regularly as fertilizer. It has been recognized that potassium is needed by the plant in large quantities for generating high yields with improved quality of produce. Potassium is important in photosynthesis, the basic process in plant production by which the energy from sunlight is converted to carbohydrates. The results reported by Skogley ${ }^{3}$ have shown the serious consequences of $\mathrm{K}$ deficiency on plant development in areas where warm and dry winds are common during the growing season. In addition, potassium speeds up the flow of assimilates, favors protein formation, improves the effect of $\mathrm{N}$, increase water-use efficiency and tolerance to salinity. ${ }^{4}$ The use of results from experiments of short duration has sometimes led to mistaken fertilizer advice. As farming is a long-term activity, experimentation should be similarly long term. ${ }^{5}$ When the soil $\mathrm{K}$ content is already high, there is little or no effect of $\mathrm{K}$ fertilizer on crop yields in the first few seasons of an experiment. ${ }^{6}$ Most tropical soils are highly weathered, and many are acidic and low in bases. They have a low cation exchange capacity and are unable to adsorb large quantities of $\mathrm{K}$ from fertilizers on the exchange complex. ${ }^{7}$ The total $\mathrm{K}$ requirement of the crop must be considered when determining the fertilizer requirement of a crop. The improved varieties of plants with high yield potentials generally take up more $\mathrm{K}$ than traditional varieties and require a correct balance between $\mathrm{N}, \mathrm{P}$ and $\mathrm{K}$ fertilization for realizing optimal yields. ${ }^{8,9}$ Large quantities of potassium are utilized by the intensive systems of vegetable production, and to ensure a high yield from such crop sequences, soil fertility has to be maintained at high levels. In year round commercial agriculture which prevails in the upcountry of Sri Lanka where the crops are high yielding, soils may rapidly be depleted of $\mathrm{K}$, unless its removal is adjusted by the addition of $\mathrm{K}$ fertilizers on a regular basis. On the other hand, excessive additions of potash may lead to a $\mathrm{K}$ build up in soil which may even lower the magnesium availability to plants.10

There is hardly any reported experimental evidence on the effect of longterm application of Kon the yield of vegetable crops in the Upcountry Intermediate Zone of Sri Lanka. A field experiment was therefore conducted to investigate the long-term effect of fertilizer $\mathrm{K}$ on a cropping sequence that is being followed in this region. 


\section{METHODS AND MATERIALS}

A long-term field experiment was conducted on a Red Yellow Podzolic soil (Table 1) at the Regional Agricultural Research Centre, Bandarawela, where four levels of Potassium $\left(0,25,50\right.$ and $100 \mathrm{~kg} \mathrm{~K}_{2} \mathrm{O} / \mathrm{ha}$ ) were tested on a sequence of crops in a randomized complete block design with six replicates. The plot size was $3 \mathrm{~m} \times 2.5 \mathrm{~m}$. Nitrogen and phosphorus levels were kept constant at $200 \mathrm{~kg}$ $\mathrm{N} / \mathrm{ha}$ and $150 \mathrm{~kg} \mathrm{P}_{2} \mathrm{O}_{5}$ /ha respectively, for cabbage, tomato and pole bean. The potato crop received $150 \mathrm{~kg} \mathrm{~N} / \mathrm{ha}$ and $150 \mathrm{~kg} \mathrm{P}_{2} \mathrm{O}_{5} / \mathrm{ha}$. The plan of randomization was not changed during the entire period of the experiment. Potato (Diamond), cabbage (Gloria F1), tomato (KWR), pole bean (KWG), cabbage (Hercules), potato (Krushi), cabbage (Hercules), tomato (Caraibe), pole bean (KWG) and cabbage (Hercules) were grown sequentially during the experimental period from Maha 86/87 to Maha 91/92. During Maha 1988/89, crop was not planted due to civil disturbances in the country.

Table 1: Some chemical characteristics of the experimental soil.

\begin{tabular}{lc}
\hline Property & Content \\
\hline pH(1:1, soil: $\left.\mathrm{H}_{2} \mathrm{O}\right)$ & 4.9 \\
Total N (\%) & 0.15 \\
Olsen P (ppm) & 13.0 \\
${ }^{*}$ Exchangeable K $(\mathrm{me} / 100 \mathrm{~g})$ & 0.33 \\
Organic matter $(\%)$ & 2.3 \\
\hline
\end{tabular}

" $\mathrm{NH}_{4} \mathrm{OAc}$ extraction

Spacing, dose and time of application of fertilizer for each crop is shown in Table 2. Nitrogen was applied as urea, $\mathrm{P}$ as concentrated super phosphate and $\mathrm{K}$ as muriate of potash.

The crops were grown under rainfed condition with supplementary irrigation whenever necessary. The fields were maintained in a weed free condition throughout the experiment.

Six composite soil samples were collected from each replicate before commencing the experiment. The chemical analysis of soil from the experimental field at the commencement of the experiment is given in Table 1. Soil samples were also collected from each plot after each crop and analyzed for $\mathrm{NH}_{4} \mathrm{OAc}$ extractable $\mathrm{K}$. 
Table 2: Spacing and fertilizer application schedule.

\begin{tabular}{|c|c|c|c|c|c|}
\hline \multirow[t]{2}{*}{ Crop } & \multirow{2}{*}{$\begin{array}{l}\text { Spacing } \\
\text { (cm) }\end{array}$} & \multirow{2}{*}{$\begin{array}{c}\text { Time of } \\
\text { application }\end{array}$} & \multicolumn{3}{|c|}{ Fertilizer application Schedule } \\
\hline & & & $\mathbf{N}$ & $\mathrm{P}$ & $\mathrm{K}$ \\
\hline \multirow[t]{2}{*}{ Potato } & $30 \times 60$ & Basal & $1 / 2$ & All & All \\
\hline & & $4 \mathrm{WAP}^{*}$ & $1 / 2$ & - & - \\
\hline \multirow[t]{3}{*}{ Cabbage } & $50 \times 50$ & Basal & $1 / 3$ & All & All \\
\hline & & 3 WAP & $1 / 3$ & - & - \\
\hline & & $6 \mathrm{WAP}$ & $1 / 3$ & - & - \\
\hline \multirow[t]{3}{*}{ Tomato } & $50 \times 50$ & Basal & $1 / 3$ & All & All \\
\hline & & 3 WAP & $1 / 3$ & - & - \\
\hline & & $6 \mathrm{WAP}$ & $1 / 3$ & - & - \\
\hline \multirow[t]{2}{*}{ Pole bean } & $45 \times 45$ & Basal & $1 / 2$ & All & All \\
\hline & & 4 WAP & $1 / 2$ & - & - \\
\hline
\end{tabular}

•WAP-Weeks After Planting.

\section{RESULTS}

The effect of addition of potassium on the yield of vegetable crops is given in Table 3. Potato in Maha 86/87, cabbage in Yala 1987 and tomato in Maha 87/88 crops did not show any significant yield response to addition of potassium. However, application of potassium at $25 \mathrm{~kg} \mathrm{~K}_{2} \mathrm{O} /$ ha resulted in a significant yield increase for pole bean in Yala 1988 and cabbage in Yala 1989 over the control. Application of 50 and $100 \mathrm{~kg} \mathrm{~K} \mathrm{O} /$ ha did not show significant increase in yield over $25 \mathrm{~kg} \mathrm{~K} \mathrm{~K}_{2} \mathrm{O} / \mathrm{ha}$ during the above two seasons.

Potato in Maha 89/90 gave a significant yield response to addition of $50 \mathrm{~kg}$ $\mathrm{K}_{2} \mathrm{O} /$ ha, but cabbage in Yala 1990, tomato in Maha 90/91, pole bean in Yala 1991 and cabbage in Maha $91 / 92$ showed significant yield response to the addition of $100 \mathrm{~kg} \mathrm{~K}$ O/ha.

\section{DISCUSSION}

If the experiment was conducted for only three seasons an erroneous conclusion may have been drawn that fertilizer $\mathrm{K}$ is not required for crops grown on this soil. This study demonstrates the importance of long term experimentation in the fertilizer response studies. It may be suggested that $100 \mathrm{~kg} \mathrm{~K}_{2} \mathrm{O} / \mathrm{ha}$ per season may be a suitable level of fertilizer application for year round 


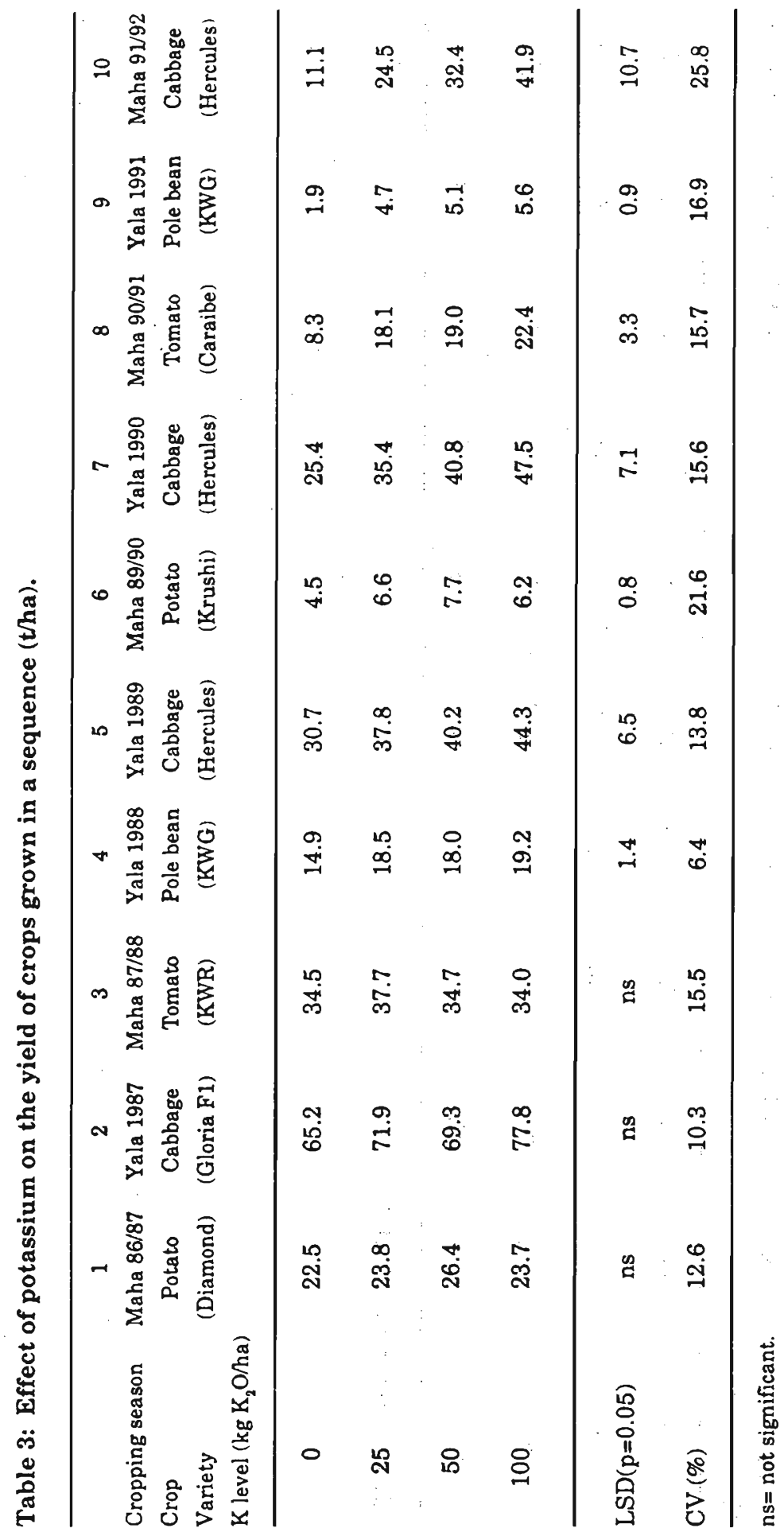




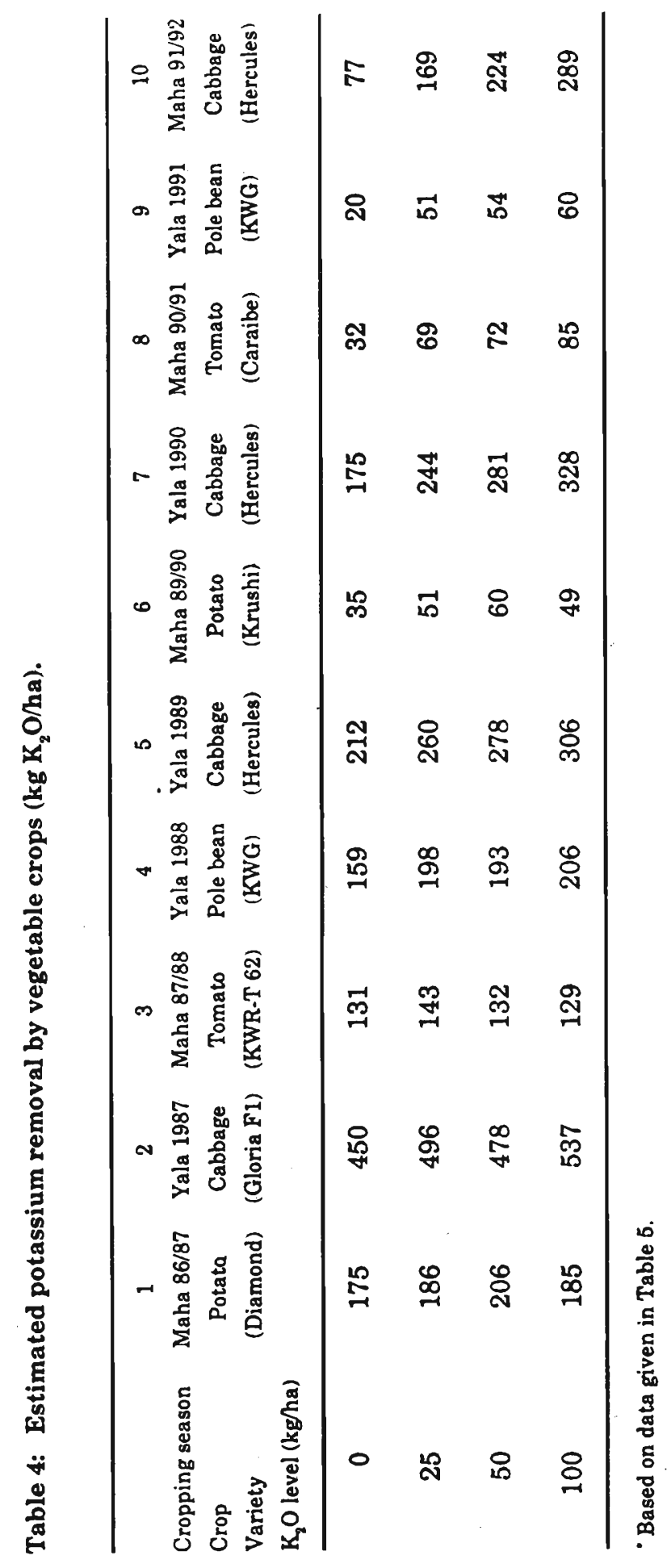


vegetable cultivation in order to attain high yields while maintaining soil $\mathrm{K}$ at a sufficiency level. These results are in agreement with the findings of Wijewardena \& Amarasiri. ${ }^{11}$

The lack of response to potassium during the first three seasons and the positive responses obtained later may be understood by considering the exchangeable soil $\mathrm{K}$ content determined at the end of each season (Fig. 1). The soil $\mathrm{K}$ content of the control plots as well as those receiving 25 and $50 \mathrm{~kg} \mathrm{~K} \mathrm{~K}_{2} \mathrm{O} / \mathrm{ha}$ continued to decline after the third season except at the end of the ninth season for the $50 \mathrm{~kg} \mathrm{~K} \mathrm{O} / \mathrm{ha}$ treatment. The soil potassium content of the control treatment dropped upto $0.1 \mathrm{me} / 100 \mathrm{~g}$ at the end of the sixth season. The yield responses obtained to addition of $\mathrm{K}$ fertilizer during the fourth season may be attributed to a lowering of soil $\mathrm{K}$ values in the control plots.

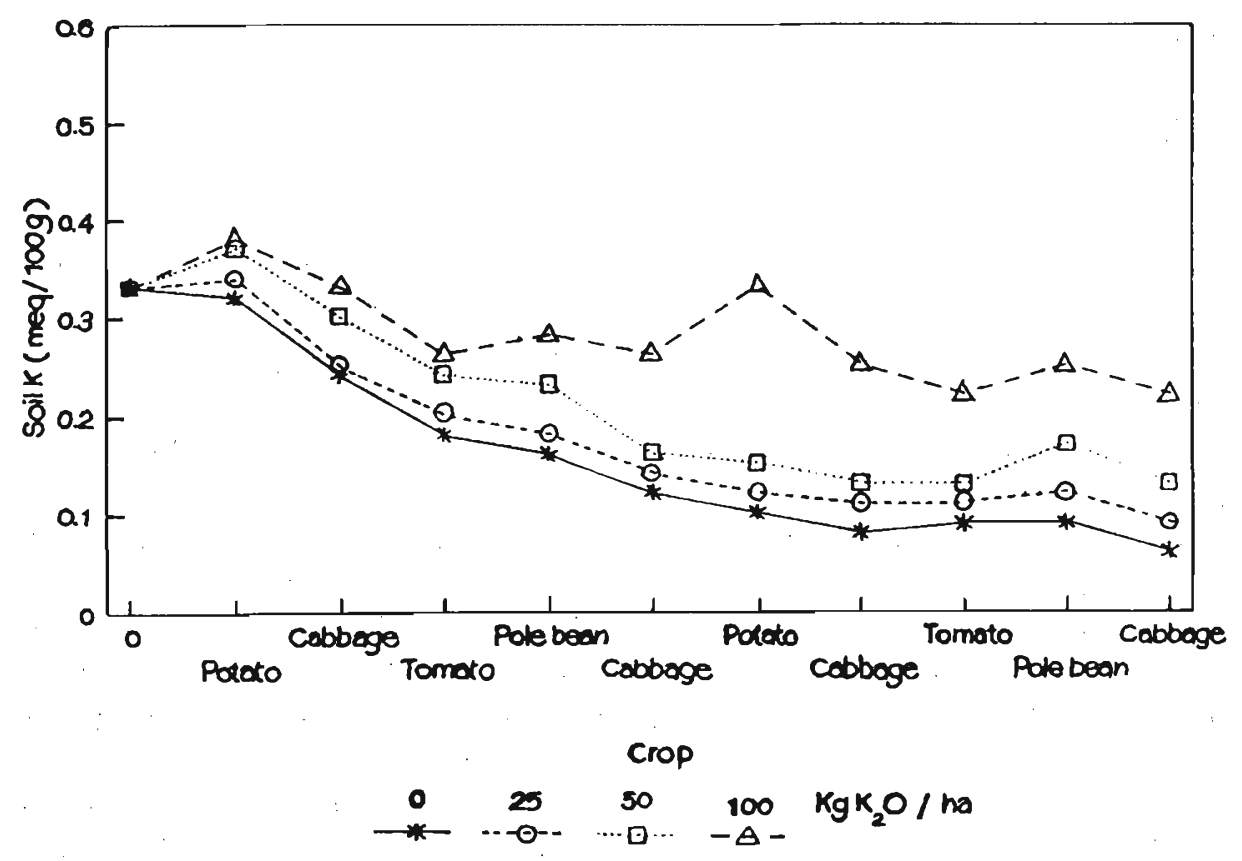

Figure 1: Soil $\mathrm{K}$ after each crop.

The study has clearly demonstrated the effect of crop removed on the depletion of soil $\mathrm{K}$ level. The amount of $\mathrm{K}$ removed by potato, bean, cabbage and tomato are shown in Table 5 . Using these values the $\mathrm{K}$ removal by crops during each of the ten seasons is given in Table 4. Although bean crop removes more $\mathrm{K}$ than cabbage on a per ton basis (Table 5) yet cabbage removed large quantities of potassium compared to other crops from the field owing to its higher biomass production (Table 4). These results agree with the findings of Wijewardena \& Amarasiri. ${ }^{11}$ The extractable soil $\mathrm{K}$ content declined after the cabbage crops grown in seasons 2 (Yala 87), 5 (Yala 89), 7 (Yala 90) and 10 (Maha 91/92) . 
Likewise, soil $\mathrm{K}$ content did not show much decline or even increased occasionally with addition of $100 \mathrm{~kg} \mathrm{~K}_{2} \mathrm{O} /$ ha during seasons when comparatively low amounts of $\mathrm{K}$ may have been removed from soil as with pole bean in seasons 4 and 9 and potato in season 6 . These results show how the potassium content in soil can be rapidly influenced by the type of cultivated crop. Hence, potassium fertilizer should be applied in accordance with the needs of the different crops. ${ }^{12}$

Table 5: Nutrient uptake (kg/ha) by vegetable crops (calculated for the whole plant on the basis of 1 ton yield). ${ }^{4}$

\begin{tabular}{lccccc}
\hline Crop & $\mathrm{N}$ & $\mathrm{P}_{2} \mathrm{O}_{5}$ & $\mathrm{~K}_{2} \mathrm{O}$ & $\mathrm{MgO}$ & $\mathrm{S}$ \\
\hline Potato & 4.4 & 2.0 & 7.8 & 1.0 & 0.5 \\
Bean & 8.7 & 2.7 & 10.7 & 2.0 & - \\
Cabbage & 5.3 & 1.2 & 6.9 & 0.9 & 1.2 \\
Tomato & 2.8 & 1.3 & 3.8 & 0.5 & 0.6 \\
\hline
\end{tabular}

Taking into consideration, the results of this experiment, it could generally be considered that in a cropping sequence, a crop that removes low quantities of $K$ by virtue of its yield potential, when followed by another crop in the sequence will normally give high yields with low quantities of applied $\mathrm{K}$ due to the accumulation of exchangeable $\mathrm{K}$ from the previous crop. On the other hand, where crops remove high quantities of $\mathrm{K}$, application of potash is necessary for succeeding crops in order to maintain the $\mathrm{K}$ status of the soil. The results of the experiment reported here suggest that application of at least $100 \mathrm{~kg} \mathrm{~K}_{2} \mathrm{O} / \mathrm{ha}$ per crop is needed for vegetable crops grown in this region. This will be an economical approach to the farmers who generally apply almost 3-4 times as much as this amount. Therefore, it is obvious that even at fluctuating vegetable prices and ever increasing fertilizer prices in Sri Lanka, there is economical benefit to the farmers if they apply $100 \mathrm{~kg} \mathrm{~K}_{2} \mathrm{O} / \mathrm{ha}$.

\section{Acknowledgements}

Authors gratefully acknowledge financial assistance by the Canadian International Development Agency (CIDA) and Natural Resources, Energy and Science Authority (NARESA), M.K.G. Yatagama for the chemical analysis, U.W.S.P. Yapa for continuing the experiment during the Maha 91/92 season, when the main author was on study leave and N.K.P.K. Nagasinghe for typing the manuscript. 


\section{References}

1. Panabokke C.R. (1967). The soil of Ceylon and use of fertilizers. pp. 151. Metro Printers Ltd., Colombo, Sri Lanka.

2. Wijewardena J.D.H.(1996). Fertilizer management under intensive cropping systems in Sri Lanka. Paper: Regional Workshop on Fertilizer Concepts with Special Reference to Organic Fertilizers, 6-9 May 1996, Fertilizer \& Pesticide Authority and the Fertilizer Advisory, Development and Information Network for Asia and the Pacific, Tagaytay, Philippines.

3. Skogley E.O. (1976). Potassium in Montana soils and crop requirements. Research Report 88. Montana Agricultural Experimental Station, Bozeman, USA.

4. Kemmler G. \& Hobt H. (1986). Potash a product of nature. pp. 112. Landwirtschaftliche Forschungsanstalt, Buntehof, Federal Republic of Germany.

5. Gruber P. (1987). Methodology of potash fertilizer recommendations. Proceedings 20th Colloquium of the International Potash Institute, Bern, Switzerland. pp.409-421.

6. Heathcote R.G. (1974). The use of fertilizers in the maintenance of soil fertility under intensive cropping in northern Nigeria. Proceedings 10th Colloquium of the International Potash Institute, Bern, Switzerland. pp. 467-474.

7. Kaddar T., Russel D.A. \& Cooke G.W. (1984). The vital role of potassium fertilizers in tropical agriculture. Technical Bulletin 29, International Fertilizer Development Centre, Muscle Shoals, Alabama, USA.

8. Munson R.D. (1982). Potassium, calcium and magnesium in the tropics and subtropics. Technical Bulletin 23, International Fertilizer Development Centre, Muscle Shoals, Alabama, USA.

9. Cooke G.W. (1986). Nutrient balances and the need for potassium in humid tropical regions. Proceedings 13th International Congress of the International Potash Institute. Bern, Switzerland. pp. 17-35.

10. Yadav B.S. \& Swami B.N. (1988). Effect of potassium fertilization on dry matter yield on composition, and uptake of nutrient by maize and change in soil potassium on cropping. Indian Journal of Soil Science Society 36 (4): 739-742. 
11. Wijewardena J.D.H. \& Amarasiri S.L. (1993). Response of vegetable crops in a cropping sequence to $\mathrm{K}$ and $\mathrm{Mg}$ fertilizers in the upcountry intermediate zone. Tropical Agriculturist $\mathbf{1 4 9}$ (in press).

12. Zhu W.H. (1981). Preliminary report on the study of rotational distribution of K-fertilizer in a triple cropping rotation in one year. Journal of Soil Science $6: 13-15$. 